\title{
The Challenges of Accompanying Families in Light of the Apostolic Exhortation Amoris Laetitia
}

This article discusses four specific pastoral challenges associated with accompanying families presented in Pope Francis' Apostolic Exhortation Amoris Laetitia. The first challenge is to come to a new understanding of pastoral care of families, which should primarily include parishes and the families that belong to them. The second challenge is pastoral concern for couples and their bond of marriage and maturation of marital love. The third challenge involves helping married couples in the spiritual life of their families. The fourth and final challenge is accompanying divorced people who are living in new unions and helping them to discern their moral responsibility, which will enable them to interpret God's teaching and seek the path to reconciliation with God and the Church.

Key words: challenges, Amoris Laetitia, accompanying the family, maturation of love, family spirituality, discernment with the divorced.

In Pope Francis' Apostolic Exhortation Amoris Laetitia, the words "accompany" and "accompaniment" are used around 60 times. They specify what is broadly understood as pastoral care of families. In the

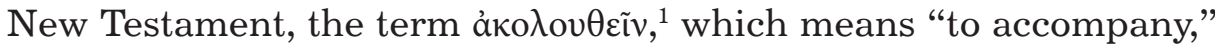
is most often used in reference to accompanying Jesus (see Mt 4:20, 22, 25; 20:29; Mk 6:1; Lk 23:27; J 1:37, 38, 40, 43; Rev 14:4). The term is

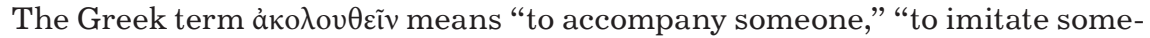
one," "to follow someone," "to walk with someone." Por. H.G. Liddell, R. Scott, H.S. Jones, R. McKenzie, A Greek - English Lexicon, Oxford 1996, pg. 52. 
Pastoral theology also used to signify Jesus accompanying the Apostles (Acts 13: 43). In this way, walking with Jesus and the Church is a condition for pastoral accompaniment, and one should learn the Lord's ways from him (See Jn 4: 1-26; 12: 26; Lk 24: 13-35).

According to Pope Francis, God first accompanies man through his presence and his grace. ${ }^{2}$ The Lord's word is a companion in family life, and it shows families the goal of their path to God, especially those families that are undergoing crisis and experiencing suffering. Jesus accompanies the Church in the difficulty it experiences in passing on the Gospel on the family ${ }^{3}$ at various stages of life and in different situations. "The Church wishes to humbly and compassionately reach out to families and 'to help each family discover the best way to overcome any obstacles it encounters." "5 Based on Evangelical principles ${ }^{6}$ and imbued with a new style, the pastoral accompaniment of families must be positive and hospitable in order to gradually deepen understanding of the Gospel. ${ }^{7}$ Pastoral conversion is necessary to accompany families ${ }^{8}$ because it changes the pastoral approach from bureaucratic and soulless to one of accompanying others and bringing them God and healing. ${ }^{9}$

The Church has extensively discussed what needs to be done to improve the pastoral care of families. ${ }^{10}$ In addition to presenting many tasks that need to be performed, the Apostolic Exhortation Amoris Laetitia formulates which tasks present specific challenges and require effort, sacrifice, and are often a test of competence and resilience. Undoubtedly, it is necessary for the Church to take an active interest

2 See Francis, Apostolic Exhortation: Amoris Laetitia numbers 63, 74, 89, 120, 134, and 291, among others. Hereafter abbreviated as AL. Ibid, 22, 60 .

See John Paul II, Apostolic Exhortation: Familiaris Consortio, 65. Hereafter abbreviated as FC; AL 217-258.

AL 200.

J. Golen, The Renewal of Pastoral Care of the Family in the Light of the Apostolic Exhortation Amoris laetitia, "Roczniki Teologiczne" 64(2017) no. 6, pgs. 96-104. AL 38 .

Francis, Apostolic Exhortation: Evangelii Gaudium, 25.

See R. Hajduk, Apologetyka pastoralna. Duszpasterska odpowiedź Kościoła na wyzwania czasów wspótczesnych, Cracow 2009, pgs. 193-253.

SeeJ.Kamiński,Zadaniaduszpasterstwa rodzin wświetleadhortacji apostolskiej "Familiaris consortio" i dokumentów Kościoław Polsce. Studiumz duszpasterstwa rodzin, Lublin 2009. A printed doctoral dissertation contained in the Catholic University of Lublin Library Archive. 
in the family and make an extra effort in order to accompany the family. This requires pastoral conversion and proper formation as well as patience and perseverence in doing what is necessary to meet and address these challenges.

Among the different pastoral challenges, the most important is to arrive at a new understanding of pastoral care for families. Presently the Church emphasizes that the pastoral care of the parish and families founded on the sacrament of marriage must be the focus. ${ }^{11}$ In this way, theology pastoral care of families can become closer to the people, outgoing, and inclusive. ${ }^{12}$ Before now, care for families was understood as the organization of a network of family clinics, meetings with engaged couples, and actions and courses that involved only few couples. Now, however, care should be offered and given to many couples in order to help them strengthen their faith and mature in love. ${ }^{13}$ Accompanying engaged and married couples is to help them learn and live the spirituality of the family. An increasing challenge today, however, is to fully care for and gently and responsibly accompany divorced people living in new relationships.

\section{A New Understanding of Accompaniment}

Heretofore the Church's teaching has emphasized that bishops and priests provide pastoral care to families by supporting them in realizing their role in the Church. ${ }^{14}$ The Church also points out that consecrated persons play a role in these efforts because their charisms serve to enliven and strengthen family life by showing the importance of faith, loyalty, sacrifice, dedication, purity, and selflessness in daily life. ${ }^{15} \mathrm{As}$ witnesses to the spirituality of communion, consecrated individuals also engage in concrete activities and pastoral tasks. ${ }^{16}$ The Church has also acknowledged that the lay faithful minister pastorally, but they serve primarily as specialists, family advisers, and consultants in various Church bodies. ${ }^{17}$

\footnotetext{
$11 \quad$ See AL 200, 202.

12 Ibid, 230, 299, 312.

13 Ibid, 211, 230.

14 See FC 73; W.Śmigiel, Podmiot duszpasterstwa rodzin, in Duszpasterstwo rodzin $w$ parafii, J. Goleń, D. Lipiec (ed.), Lublin 2016, pgs. 39-40.

15 See FC 16, 74; AL 202.

16 See Śmigiel, Podmiot duszpasterstwa rodzin, pgs. 41-43.

$17 \quad$ FC 75
} 
Pastoral theology

John Paul II emphasized that particular parishes "remain the more immediate and more effective subjects of operation for putting the pastoral care of the family into practice;" in this way, each parish community with the help of grace is responsible for its own development. ${ }^{18}$ He called for every ecclesial community to adequately and organically provide pastoral care to families. ${ }^{19}$ Pope Francis, on the other hand, emphasizes the preferential role of the parish, stating that the "main contribution to the pastoral care of families is offered by the parish, which is the family of families." ${ }^{20}$ Such an approach entails not only a real concern for the family, but also an increase in the evangelization of such parish communities as families. ${ }^{21}$ What seems necessary, therefore, is to shift the emphasis of pastoral care in every ecclesial community to focus on engaged and married couples as well as the family. This care requires the real commitment on the part of pastors and more involvement on the part of the lay faithful.

A new understanding of the subject of pastoral care of families refers also to recognizing families based on the sacrament of marriage. John Paul II called the family the subject of pastoral care, ${ }^{22}$ but he meant this mainly in refernce to evangelization and apostolates in the family. Pope Francis, however, stated that "Christian families, by the grace of the sacrament of matrimony, are the principle agents of the family apostolate, above all through 'their joy-filled witness as domestic churches." "23 He repeatedly emphasized that married couples need to give witness to and accompany engaged couples, married couples, as well as couples living in irregular situations in their formation. ${ }^{24}$

This goal can be achieved through the religious formation of married couples ${ }^{25}$ who themselves can then cooperate with priests in the service of families. According to Pope Francis, the pastoral formation of families does not concern only the formation of a few married couples involved in family movements and communities, but also the preparation of many couples to accompany others in their parishes. Ibid, 70 .

19 John Paul II, Apostolic Exhortation, Ecclesia in Europa, 91. AL 202.

J.J.Pérez-Soba, La pastorale familiare. Tra programmazioni pastorali egenerazione di una vita, Siena 2013, pg. 93. 
It is necessary to appreciate the potential of married couples who are already formed and being formed in family associations and who give witness to their faith, are involved in the apostolate, and accompany spouses. For, such families can be like leaven within parish formation. However, in order to prepare a sufficient number of families for the role and responsibility of accompanying engaged and married couples as well as as couples in irregular situations, it is necessary to first organize formation in parishes which is supported, on the one hand, by parish groups and, on the other hand, by diocesan centers. ${ }^{26}$

\section{Care for the Love of Spouses}

Marital love, which spouses vow to each other when they enter into the sacrament of marriage, needs to be supported and sustained. The inseparable marital union that is established by God assures his grace; however, the realization of the communion of the spouses in marriage (see Gadium et Spes 12,48) requires that the spouses show and exercise their own concern for their mutual bond and ensure that their love matures. Given the increasing failure of many marriages, this is an urgent task. For this reason, the Pope's statement that the pastoral care of families must become a pastoral commitment is understandable. ${ }^{27}$ Such a transformation of the pastoral care of families also requires a change in pastoral mentality, effort, and competence.

In his exhortation, Pope Francis points out ways to strengthen the bond and concern that is necessary for marital love to mature.$^{28} \mathrm{His}$ indications concern not only the spouses' cultivation of their mutual bond, but also the Church's support in this area. Pastoral failures and negligence in this area deprive spouses of the opportunity to perceive the situation correctly and leaves them on their own to deal with the difficulties that they experience. ${ }^{29}$ Therefore, it is worthwhile to examine the specific ways to cultivate spousal love that Pope Francis' exhortation proposes and to seek adequate ecclesial activities to address these concerns.

See J. Granados, S. Kampowski, J.J. Pérez-Soba, Amoris laetitia. Accompagnare, discernere, integrare. Vademecum per una nuova pastorale familiare, Siena 2016, pgs. 35-38.

AL 211, 224.

See Ibid, 120-157, 163-164.

See Ibid, 36-37. 
In his exhortation, Pope Francis first points out that married couples need to perceive God's action in their conjugal love. ${ }^{30}$ In the sacrament of marriage, the spouses enter into not only a relationship with each other, but also with God. Only through God's love can conjugal life attain its fullness. Therefore, in pastoral care, ministers need to remind spouses that, from the beginning of their marriage, God has been and is constantly with them and giving them his grace to realize their vocation and mission. ${ }^{31}$

According to Amoris Laetitia, spouses must strive in marriage to strengthen their friendship. Thanks to such a friendship, they will be able to understand the value and sacredness of each other and remain free from the need to possess each other. ${ }^{32}$ Cultivating their mutual friendship will help the married couples to strengthen their communio personarum. Marital love requires constant care and cultivation so that it can mature. In addition, marital love can always increase and develop because it participates in the Holy Spirit, who is infinite. Spouses respond to God's grace and strive to develop charity through different acts,$^{33}$ and the circumstances of daily life create opportunities to show charity. The difficulties that couples experience in marriage do not mean that their love has ended; rather, they are an invitation to the spouses to love more deeply, to learn to forgive, and to love the other for who the person is. ${ }^{34}$ In order help marital love to mature, the Church proclaims the word of God; offers the sacraments; and provides adult catechesis, formation in family associations, spiritual guidance, family counciling, as well as retreats and workshops intended to help couples improve their communication with each other.

Dialogue between spouses is a privileged and indispensible way to develop and express charity both in marriage and in a family. However, to dialogue well requires long and arduous practice. ${ }^{35}$ Spiritual unitythe communion of persons-is the basis for spousal dialogue. Amoris Laetitia contains valuable and practical indications regarding marital dialogue in points $136-141 .{ }^{36}$ Since these indications are an integral part of the papal document, they should be included and promoted

\footnotetext{
$30 \quad$ See Ibid, 134.

31 See AL 121.

32 See Ibid, 123-127.

33 See Ibid, 134.

$34 \quad$ See Ibid, 135.

$35 \quad$ Ibid, 136.

36 See Ibid, 137-141.
} 
not only in the pastoral care of engaged and married couples, but also through social media and on the Internet.

The guiding principle of Francis' exhortation is cultivating the joy of love (amoris laetitia) in marriage. Joy expands hearts and lets spouses and families relish life even when pleasure subsides and difficulties and suffering occur. ${ }^{37}$ Such joy flows from cherishing and admiring that which is beautiful and holy in a person. ${ }^{38}$ The action of the paschal law of sacrifice is also evident here ${ }^{39}$ Emphasizing the role of respect, Pastoral admiration, and appreciation, and cooperation between spouses in pastoral care can help spouses maintain the joy of love in their marriage. The Pope's advice is possible to follow in every marriage. For this reason, it is worth reminding couples of it often in ecclesial preaching, disseminating it in the media and on the Internet, and popularizing it is Catholic publications.

Spouses must integrate their emotional lives if their marital love is to grow and mature. Emotional affectivity is affected by egoism; therefore, it must be integrated with the total love that is conjugal love. ${ }^{40}$ Although many engaged couples mistakenly think otherwise, love is not just strong feelings and emotions ${ }^{41}$ that enclose them in their own desires and mask self-centeredness. An emotional life that is free from egoism, liberated from the tendency to dominate, and includes serving the common good is a sign of maturity. ${ }^{42}$ Casting off egoism strengthens a lasting marital relationship through the sexual union of the spouses. ${ }^{43}$ Sexuality entails a capacity to express a love in which each person becomes a gift to the other. ${ }^{44}$ Unfortunately, spouses sometimes deify eros in marriage. As a result, they violate the dignity of the other person by treating the other person as an object..$^{45}$ In this

$37 \quad$ See Ibid, 126, 129.

38 See Ibid, 127-128.

39 See Goleń, The Renewal of Pastoral Care of the Family in the Light of the Apostolic Exhortation Amoris Laetitia, pgs. 100-103.

AL 142.

J. Goleń, Miłość maṫ̇eńska wświetle badań narzeczonych, "Studia nad Rodziną" 18(2014), no 2(35), pgs. 114-116.

See AL 145-146.

See Ibid, 147-152.

See Giovanni Paolo II, L'uomo-persona diventa dono nella liberta dell'amore. Udienza generale (16.01.1980), in Insegnamenti di Giovanni Paolo II, III/1 (1980), pgs. 148-152.

Benedict XVI, Encyclical Letter: Deus Caritas Est (December 25, 2005), 4; AL 147. 
case, sexual acts become separated from love. This is why sexual intercourse between spouses requires that they learn to control their emotions and impulses and direct them toward making a gift of self to the other that results in self-realization. ${ }^{46}$ To this end, each spouse must learn the meaning of the body, marvel at the dignity and value of the other person, and treat the other as a gift that enriches their encounter. ${ }^{47}$ Given the current cultural climate, there is a need for wider dissemination of what integration of one's emotional life and love means and raising individuals to have sexual integrity and inclinations. In addition to the forms already indicated, it is worthwhile to appreciate the role of the spouses' witness.

The institution of marriage, including the spouses' specific obligations to each other, God, the Church, and society, serves as a safguard and tool of mutual marital love. ${ }^{48}$ The modern Church considers the witness of idissoluble communion and the holiness of marriage as the most important part of the spouses' apostolate (See Apostolicam Actuositatem 11). ${ }^{49}$ In addition to the spouses' trust in each other, which spurs them to fulfill their mutual obligations, it is important to remember the process of the transformation, maturation, and strengthening of love. ${ }^{50}$ Maturation requires that the spouses continually choose each other and decide to belong to each other. For, love surpases emotions and states of the spirit-it is a decision of the heart that encompasses a person's entire existence. It is possible to make this decision if spouses continually invoke the Holy Spirit, which enkindles love. ${ }^{51}$ The faithful, who often doubt, urgently need to have their trust in the action of God's grace in the sacrament of marriage and in married life awakened..$^{52}$

AL 148.

See Ibid, 151-152.

Ibid, 32, 131.

See FC 20.

AL 220, 124; por. AL 100.

See Ibid, 163-164.

See Ibid, 36-37. 


\section{Supporting Spouses in Their Lives Through Family Spirituality}

Only in recent decades has interest in conjugal and family life increased..$^{53}$ Some family organizations are leading the way in promoting the spirituality of the family, and Pope Francis dedicates an entire chapter of Amoris Laetitia to this topic. Therefore, it is worthwhile to consider more closely the most important features of the spirituality of the family that the Pope writes about and strive to ensure that the faithful hear about them.

First, in Amoris Laetitia, Pope Francis emphasizes that the spirituality of the family is a spirituality of supernatural communion that consists in the presence of the Holy Trinity in the sanctuary of marital unity (communion) that gives glory to God. It is the Lord who causes the mutual union to mature. The Pope describes the spouses' union with God using the word "mystical." ${ }^{54}$ Marital union also has a paschal dimension because the spouses participate in the mystery of Christ's cross and share in the mystery of His resurrection. ${ }^{55}$ In this way, the spouses' transformation and sanctification are brought about. ${ }^{56}$ Family prayer, common participation in the Eucharist, and the reception of the Lord's body are the privileged means of strengthening paschal faith. ${ }^{57}$

Exclusivity and freedom are hallmarks of the spirituality of the family. Following the example of God's fidelity, spouses mutually belong to each other-their hearts belong to each other because each spouse is a sign and instrument of the Lord's closeness. ${ }^{58}$ At the same time, God is the source of freedom, which is why the exclusivity of marriage is connected with a proper autonomy. A spouse who is united with God discovers that the other spouse is not his or her property, but rather that the other belongs to the One and Only Lord, who wants to be the center of man's life. This deep and personal realm of a person's relationship with God allows the spouses to find a sense of meaning in God's love and be healed of wounds arising from human relationships. The Holy Spirit makes interior freedom that allows God to be at the center of one's life possible, and individuals must ask for this freedom

53 See K. Lubowicki, Duchowość matżeńska w nauczaniu Jana Pawła II, Cracow 2005.

$54 \quad$ See AL 316

55 See Ibid, 317.

56 Ibid, 62 .

$57 \quad$ Ibid, 318.

$58 \quad$ Ibid, 319. 
Pastoral theology

through prayer. ${ }^{59}$ Pastoral care should also support and promote such an understanding of exclusivity.

Family spirituality is also characterized by mutual care and support. God's love is manifested to the spouses through their concrete charitable words and deeds. The mutual care that spouses show each other is exemplified in Jesus Christ, the incarnate Word of God, and this care reaches its climax when the spouses perceive Christ in each other. The mutual support that spouses give each other gives rise to the joy of being loved (amoris laetitia); it opens the spouses' hearts to receive and care for new life; and encourages them to help those in need. ${ }^{60}$ This feature of spirituality is connected with an invitation to the spouses to nurture their mutual care and support. Many spouses need help to learn about and fill what they notice they lack in themselves in this area.

Since many spouses nowadays place unreasonable expectations on each other in the area of conjugal love, Pope Francis distinguishes between the expectations that one can have toward another person and those expectations that only God can fulfill. In this regard, he encourages spouses to contemplate the fullness that is God and not to expect in interpersonal relationships the perfection and purity of intention that can be found only in the Kingdom of God. ${ }^{61}$ Contemplation of the divine completeness leads to an attitude of merciful love towards human weakness. At the same time, it empowers and assists people in maturing spiritually.

Both current and future priests as well as married couples, particularly those who engage in different forms of family apostolates in the Church, neeed to become familiar with marital and family spirituality.

\section{Accompaniment of and Discernment for the Divorced Who Are Living in New Relationships}

One pastoral challenge is accompanying the divorced who are living in new relationships. For decades the Church has clearly noticed these individuals and their problems and tried to show them pastoral care. ${ }^{62}$ The challenge here is that the number of couples living in irregular situations has increased, and Pope Francis has a strong desire to follow the example of Jesus, "who is the Shepherd of the hundred, not just

\begin{tabular}{ll}
\hline 59 & See Ibid, 320. \\
60 & See Ibid, 321-324. \\
${ }_{61}$ & Ibid, 325. \\
${ }_{62}$ & See FC 84.
\end{tabular}


of the ninety-nine." As such, he wants to ensure everyone's wellbeing by encouraging the faithful to reach out with love to everyone. ${ }^{63}$

The challenge of accompanying the divorced who are living in new relationships must first be recognized and met on an organizational level. To this end, dioceses need to have reconciliation centers that provide retreats, days of recollection, workshops, and consultations with specialists who can help the divorced living in irregular situations reconcile with God and their sacramental spouse ${ }^{64}$ and to repair the wrongs they have done. In Poland, there are only a little more than 20 pastoral groups that focus on divorced people living in new relationships. ${ }^{65}$ The challenge is, therefore, to prepare an appropriate number of pastors who can create and serve such groups in each diocese. In addition, spouses who are separated or in crisis need easy access to consultations with specialists in the fields of information, counseling, and mediation.

Before the divorced investigate the marriage annulment process, they need to be assured of legal and canonical help. The Church's current law is very sensitive to the fact that individuals give defective marital consent and that a high percentage of claims about the invalidity of marriage are confirmed, which is a source of hope to many people that they will be able to canonically sort out their irregular marital situations. Pastors should encourage and help the divorced who are living in new relationships turn to the ecclesial tribunal when these couples suspect that their marriages are canonically invalid, especially when such individuals are resistant to doing so themselves. On the diocese's part, it is very important for the marriage tribunal to be not only present, but also accessible and efficient in its proceedings. ${ }^{66}$

There is no reason for those living in irregular relationships to distance themselves from a life of faith and the community of the Church. Indeed, they are all the more invited to join in the life of the Church and to take advantage of the support of pastors and parish groups.

\footnotetext{
$63 \quad$ AL 308-309.

64 See Ibid, 242.
}

65 See M. Habiniak, Duszpasterstwo zwiazków niesakramentalnych droga do realizacji wspólnoty z Bogiem i Kościołem. Studium z duszpasterstwa rodzin, Lublin 2016, pgs. 334-340, typescript contained in the Catholic University of Lublin Library Archive.

66 See AL 244; por. Benedict XVI, Apostolic Exhortation Sacramentum Caritatis, 29. 
Above all, they and their pastors are invited to discern the working of God in their lives as well as their situation before God. ${ }^{67}$

Discerning the moral responsibility of the divorced who are living in new relationships is, however, a considerable challenge. On the one hand, the Pope does not intend to change the norms concerning granting absolution to divorced persons living in new relationships and admitting them to receive Holy Communion. ${ }^{68}$ On the other hand, however, the Church clearly recognizes the diverse situations in which divorced people find themselves, the faithful's (lack) of moral responsibility, and the need to study these issue more deeply. ${ }^{69}$ Those who are divorced and living in new relationships should privately seek insight with the assistance of a confessor who can help them discern their responsibility for the disintegration of the sacramental marriage and whether or not they fulfilled the obligations of sacramental marriage. ${ }^{70}$ In this process of discernment, individuals should also consider their moral responsibility for their current (relationship) state, including the external conditions and circumstances of entering into a new relationship, their subjective conditions, and the new couple's current life together. An individual's personal circumstances can be such that his responsibility for moral choices is lessened. For example, a person who is living in an objectively gravely sinful situation might not actually be committing mortal sin either because of certain external conditions that do not allow him to act in accordance with a moral norm, or because of his own subjective limitations such as his great difficulty understanding the values contained in the norms or limited ability to make decisions (actus humanus). ${ }^{71}$

With regard to the possibility of receiving sacramental asbolution, it is important to examine and identify the obstacle that is preventing the individual from fully participating in the life of the Church. In the case of someone who is divorced and living in a new relationship and engaging in sexual relations (latin: more uxorio), ${ }^{72}$ otherwise known as cohabitation, it is clear that such a state is objectively incompatible

\footnotetext{
67 See AL 297.

68 See Ibid, 3, 297, 300-301, 307.

69 Ibid, 79, 298.

70 Ibid, 300 .

71 Ibid, 301-302, 305; por. Ibid 300, footnote 336; Ibid 302, footnote 344; F. Coccopalmerio, Radość miłości. Przewodnik po ósmym rozdziale adhortacji Amoris laetitia papieża Franciszka, Cracow 2017, nr 3.3.

72 See W. Góralski, Adhortacja apostolska Amoris laetitia papieża Franciszka. Prezentacja dokumentu z komentarzem do nn. 300-308, Plock 2016, pg. 59.
} 
with God's law and, for this reason and insofar as the situation persists, such an individual cannot and should not receive Holy Communion. ${ }^{73}$ If, however, the individual cannot divorce for important reasons but is sincerely sorry for his sins and is resolved before his confessor to remain completely abstinent (i.e., refrain from any acts to which only married people are entitled), then such an individual can receive absolution and Holy Communion, while resolving and striving to avoid any scandal. ${ }^{74}$ If, after receiving absolution, such an individual were to fall back into grave sin due to human weakness, then he or she may take the issue up again before a confessor. Granting such individuals absolution again would be possible if the confessor finds that an individual is contrite, regrets his or her sins, is still resolved (despite exterior conditions or subjective limitations) to live abstinently, and is ready to fulfill the exterior conditions. ${ }^{75}$

Due to the external conditions and subjective limitations mentioned above, the Pope does not wish to refuse the help of the sacraments to people who are living in new relationships and who are not ready to live in complete abstinence, but who are sincerely sorry for their sins and desire to change their way of life but are unable to realize this desire. ${ }^{76}$ While such an interpretation has been officially confirmed, ${ }^{77}$ it remains the topic of heated discussions. It is up to the bishops to interpret the Pope's encouragement in the light of the Church's teaching and local traditions and to show confessors and pastors how to proceed. ${ }^{78}$ The challenge of discernment requires humility before God, his law, and the sacraments as well as responsibility and the courage of love on the part of bishops, confessors, and the penitents themselves.

73 Congregation for the Doctrine of the Faith, Letter to the Bishops of the Catholic Church Concerning the Reception of Holy Communion by the Divorced and Remarried Members of the Faithful, (September 14, 1994), 4.

Ibid.

See W. Góralski, Adhortacja apostolska Amoris laetitia papieża Franciszka, pgs. 69-70.

AL 301, 305, footnote 351; see F. Coccopalmerio, Radość mitości, nr 3.3-3.5; 3.7-3.8.

Francis, Carta del Santo Padre Francisco a los Obispos de la Región Pastoral de Buenos Aires en respuesta al documento "Criterios básicos para la aplicación del capitulo VIII de la Amoris laetitia" (September 5, 2016).

See AL 3, 300. 


\section{WYZWANIA TOWARZYSZENIA RODZINIE W ŚWIETLE ADHORTACJI APOSTOLSKIEJ AMORIS LAETITIA}

Pastoral theology

Artykuł ukazuje niektóre wyzwania duszpasterskiego towarzyszenia rodzinie zawarte w adhortacji Franciszka Amoris laetitia. Wyodrębnione zostały cztery wyzwania, wymagające wysiłku odnowy duszpasterstwa rodzin. Pierwszym z nich jest nowe rozumienie podmiotu duszpasterstwa rodzin, którym powinna być przede wszystkim parafia i rodzina. Drugim jest duszpasterska troska o więź i dojrzewanie miłości małżeńskiej. Trzecim jest pomoc małżonkom w życiu duchowością rodziny. Czwartym wyzwaniem jest towarzyszenie osobom rozwiedzionym żyjącym w nowych związkach i pomoc w rozeznawaniu odpowiedzialności moralnej, pozwalająca im odczytać Bożą pedagogię i poszukiwać drogi pojednania z Bogiem i Kościołem.

Słowa kluczowe: wyzwania, Amoris laetitia, towarzyszenie rodzinie, dojrzewanie miłości, duchowość rodziny, rozeznawanie z rozwiedzionymi.

\section{Bibliography:}

1. Benedict XVI, Encyclical Letter: Deus Caritas Est (December 25, 2005).

2. Benedict XVI, Post-Synodal Apostolic Exhortation: Sacramentum Caritatis (February 22, 2007).

3. Coccopalmerio F. , Radość mitości. Przewodnik po ósmym rozdziale adhortacji Amoris laetitia papieża Franciszka, Cracow 2017.

4. Congregation for the Doctrine of the Faith, Letter to the Bishops of the Catholic Church Concerning the Reception of Holy Communion by the Divorced and Remarried Members of the Faithful (September 14, 1994).

5. Francis, Apostolic Exhortation: Evangelii Gaudium (Novemebr 24, 2013).

6. Francis, Carta del Santo Padre Francisco a los Obispos de la Región Pastoral de Buenos Aires en respuesta al documento "Criterios básicos para la aplicación del capitulo VIII de la Amoris laetitia" (September 5, 2016).

7. Francis, Post-Synodal Apostolic Exhortation: Amoris Laetitia (March 19, 2016).

8. Goleń J., Miłość matżeńska w świetle badań narzeczonych, "Studia nad Rodziną" 18(2014), no 2(35), pgs. 107-132.

9. Golen J., The Renewal of Pastoral Care of the Family in the Light of the Apostolic Exhortation Amoris Laetitia, "Roczniki Teologiczne" 64(2017) no. 6, pgs. 95-114.

10. Góralski W., Adhortacja apostolska Amoris laetitia papieża Franciszka. Prezentacja dokumentu z komentarzem do nn. 300-308, Plock 2016.

11. Granados J., Kampowski S., Pérez-Soba J.J., Amoris laetitia. Accompagnare, discernere, integrare. Vademecum per una nuova pastorale familiare, Siena 2016.

12. Habiniak M., Duszpasterstwo zwiazków niesakramentalnych drogą do realizacji wspólnoty z Bogiem i Kościołem. Studium z duszpasterstwa rodzin, 
Lublin 2016. A typescript contained in the Catholic University of Lublin Library Archive.

13. Hajduk R., Apologetyka pastoralna. Duszpasterska odpowiedź Kościoła na wyzwania czasów wspótczesnych, Cracow 2009.

14. John Paul II, L'uomo-persona diventa dono nella liberta dell'amore. Udienza generale (Janiary 16, 1980), in Insegnamenti di Giovanni Paolo II, III/1 (1980), pgs. 148-152.

15. John Paul II, Post-Synodal Apostolic Exhortation: Ecclesia in Europa (June, 28 2003).

16. John Paul II, Post-Synodal Apostolic Exhortation: Familiaris Consortio (November 22, 1981).

17. Kamiński J., Zadania duszpasterstwa rodzin w świetle adhortacji apostolskiej "Familiaris consortio" $i$ dokumentów Kościoła $w$ Polsce. Studium $z$ duszpasterstwa rodzin. Lublin 2009. A printed doctoral dissertation contained in the Catholic University of Lublin Library Archive.

18. Liddell H G., Scott R., Jones H.S., McKenzie R., A Greek - English Lexicon, Oxford 1996.

19. Lubowicki K., Duchowość matżeńska w nauczaniu Jana Pawła II, Cracow 2005.

20. Pérez-Soba J.J., La pastorale familiare. Tra programmazioni pastorali e generazione di una vita, Siena 2013.

21. Śmigiel W., Podmiot duszpasterstwa rodzin, in Duszpasterstwo rodzin w parafii, (ed.) J. Goleń, D. Lipiec, Lublin 2016, pgs. 35-48. 